\title{
TOWARDS A NEW STRATEGY FOR EU ENLARGEMENT - BETWEEN THE WISH FOR AN ENCOURAGEMENT, THE REALITY OF THE FATIGUE AND THE THREAT OF A DEAD END
}

\author{
Uroš Ćemalović, PhD, Associate Professor \\ Research Fellow at the Institute of European Studies \\ Trg Nikole Pašića 11, Belgrade, Serbia \\ contact@uroscemalovic.com
}

\begin{abstract}
European Union's (EU) enlargement policy is, for at least half a decade, facing a reality that, with quite some benevolence, could be defined as an orientation crisis, accompanied with a substantial lack of clarity and precision. The fact that, during the second half of 2019, both North Macedonia (NM) and Albania (AL) have not achieved the status of candidate countries was only a symptom - unfortunately not devoid of still unforeseeable internal political and economic consequences - of undeniable and profound discord between the EU member states over the future of the Union's enlargement policy. When it comes to the two countries of the Western Balkans - Serbia (SR) and Montenegro (MN) - that are already in the process of membership negotiation, their relatively poor progress in 2019 - with either no further chapters provisionally closed $(M N)$ or with only one chapter opened (SR) - only confirms the initial assessment about the fundamental crisis of this important EU policy. On the basis of scarce and mostly underdeveloped elements of the new enlargement methodology presented by the Commission in February 2020, this paper - using content analysis and scrutiny of negotiation-related polices of candidate countries - seeks to go beyond questions of conditionality and benchmarks, in order to examine some major consequences that this potentially new enlargement strategy could have. In spite of the fact that the focus of the analysis is put on some major changes the reorientation of this policy would entail, the author also examines (and, to some extent, predicts) what are the potential benefits andlor threats the new methodology could bring to both candidates and the EU itself. Without any pretention to provide final answers and apodictic conclusions, this paper proposes some elements of fine-tuning, in order to better define a potential change that encompasses the following three controversial elements: the wish for an encouragement, the reality of the fatigue and the threat of a dead end.
\end{abstract}

Keywords: EU enlargement, new enlargement methodology, policy reform, membership negotiation 


\section{INTRODUCTION}

For at least two decades that followed the fall of the Berlin wall and numerous major political and economic changes it entailed, the EU enlargement has been an undisputed success story. After the 1995 enlargement (Austria, Finland and Sweden) - whose specificity was that it concerned politically well prepared and economically solid countries, having, according to the numerous parameters, better results than the EU12 average at that time ${ }^{1}$ - the following three enlargements (2004, 2007 and 2013) have brought profound changes in the way the EU functions and prepares itself for the new member states. In this regard, the 2004 enlargement - quite often referred to as 'a big bang' ${ }^{2}$ - was particularly important, given that, out of ten new member states, eight were the countries with predominately illiberal political heritage and still not stabilised market economy. As the institutions of both the EU and member states were slowly adapting to the bigger Union $^{3}$ with richer variety of political views and backgrounds of its numerous representatives, the block's enlargement policy has also undergone various substantial changes, so much so that, for example, Bulgaria, Romania (both joined in 2007) and Croatia (joined in 2013) have been expected to fulfil procedural and substantial conditions which considerably differed compared to those applicable in previous waves of enlargement, introducing more detailed benchmarks and signalling 'a new chapter in the development of EU enlargement policy'. ${ }^{4}$ In the same vein, the regulatory framework that is (or that will be) applied to all actual candidate and potential candidate countries for the EU membership is now undergoing yet another substantial change. As of April the $1^{\text {st }} 2020$, there are five current candidate countries: Albania (AL), Montenegro (MN), North Macedonia (NM), Serbia (SR) and Turkey (TR), out of which two (AL and NM) have recently (March 25, 2020) achieved this status, ${ }^{5}$ while one (TR) is, for quite a long time, in a standstill regarding its EU accession. ${ }^{6}$ In the same time, starting from the second half of

See Kaiser, W:; Elvert, J. (eds), European Union Enlargement: A Comparative History, Routledge, 2004, $139-200$

2 See, for example, Berger, H.; Moutos, T., (eds), Managing European Union Enlargement, The MIT Press, Cambridge 2004; Zimmermann, H.; Dür, A., (eds), Key Controversies in European Integration ( $2^{\text {nd }}$ edition), Palgrave, London 2016; Haakon Ikonomou, Aurélie Andry and Rebekka Byberg (eds), European Enlargement accross Rounds and Beyond Borders, Routledge, London, 2017

3 For some major global and country-specific institutional adaptations, see Börzel, T., States and Regions in the European Union - Institutional Adaptation in Germany and Spain, Cambridge University Press, Cambridge, 2002

4 Gateva, E., European Union Enlargement Conditionality, Palgrave Macmillan, 2016

5 General Affairs Council - Coucil Conclusion 7002/20 of 25 March 2020, accessible at [https://data. consilium.europa.eu/doc/document/ST-7002-2020-INIT/en/pdf], accessed 20. June 2020

6 For a recent and comprehensive study on the relations between the EU and Turkey, see Zucconi, M., EU Influence Beyond Conditionality: Turkey Plus/Minus the EU, Palgrave Macmillan, 2019 
2019, the EU is striving to define a new set of rules dedicated to the enlargement process; some of those rules are already known, while a number of important elements is still in a chiaroscuro, tore between the wish of encouragement, the reality of enlargement fatigue and the ever-present threat of a dead-end. In the following two chapters, this paper analyses those of the enlargement-related legal and regulatory principles that are already known (Chapter 2 - Section 1), and examines some of the major potential benefits and/or disadvantages of the changes those new principles would entail (Chapter 2 -Section 2). Chapter 3 brings a per-country overview of the actual status of four (out of five) actual candidate countries, especially in regard of the new enlargement strategy. The main methods used are content analysis and comparative legal method, while the national administrative and regulatory frameworks of the candidate countries will be analysed in the context of EU conditionality.

\section{THE NEW ENLARGEMENT METHODOLOGY - AN ADMINISTRATIVE TOUCHING UP OR A CREDIBLE ALTERNATIVE}

As it was the case with numerous other important political events, the global public health crisis caused by the SARS-CoV-2 virus (and COVID-19 outbreak it provoked) was the reason why the Zagreb Summit of the EU Member States and the states of Southeast Europe (Western Balkans), ${ }^{7}$ initially planned for May 6-7, 2020, was first postponed, ${ }^{8}$ and then planned to be held via video conference. ${ }^{9}$ As it was already announced at several occasions, one of the main goals of this summit would be to enhance the process of the accession of new member states, by adopting the new enlargement methodology. Consequently, this chapter will be dedicated to the most recent official document treating exclusively this issue - the Communication from the Commission to the European Parliament, the Council, the European Economic and Social Committee and the Committee of the Regions on 'Enhancing the accession process - A credible EU perspective for the

In its official documents and press releases, the Croatian presidency tends to use the notion of Southeast Europe, while the European Commission, as the subtitle of its Communication(2020) 57 of February 5, 2020 clearly indicates, privileges the term Western Balkans. Without entering in complex and predominantly meta-legal reasons for this terminological distinction, in this paper will be used the term Western Balkans

8 Website of the Croatian presidency of the EU, Croatian Presidency postpones informal meetings in Croatia until 15 May, [https://eu2020.hr/Home/OneNews?id=236], accessed 20. June

9 Website of the Croatian presidency of the EU, On the initiative of Prime Minister Andrej Plenkovic, Zagreb Summit will be held May 6th via video conference, [https://eu2020.hr/Home/OneNews?id=257], accessed 20. June 2020 
Western Balkans' of February 5, $2020^{10}$ (hereinafter referred to as Communication(2020) 57). This relatively short document (eight pages) comprises only one substantial chapter (preceded by mostly historical introduction and followed by a technical annex dedicated to the clusters of negotiation chapters), divided in four subchapters characterised by emphatic, mainly meta-legal style, and unequal level of development. For the purposes of our analysis of the Communication(2020) 57 , we will first examine the proclamatory general principles upon which the new enlargement methodology is based (Section 2.1), before focusing on major changes the new enlargement strategy would entail (Section 2.2). Finally, once adopted, all the changes in enlargement methodology proposed by the Commission will be fully applicable to AL and NM, while negotiating frameworks for MN and SR will not be amended, 'but the proposed changes could be accommodated within the existing frameworks,' of course, with their agreement. ${ }^{11}$

\subsection{List of proclamatory general principles}

As it is often the case with the documents initiating important reform processes and - generally lengthy and hefty - law-making procedures, the Communication(2020) 57 has three important features: 1) emphatic and proclamatory style; 2) excessive use of prescriptive formulations; 3) globally low level of precision. However, even the consensus-based decision making procedure and, as it was the case for this document, long-lasting political bargaining before its final adoption, allows us to distil some grandes lignes defining general principles upon which the new enlargement methodology is based. Before focusing on each of these general principles, we will first substantiate the above-mentioned three important features of the entire document.

Primo, the overall editorial style of the Communication(2020) 57, besides the use of the usual EU's bureaucratic jargon, is excessively emphatic, attitude-oriented and too frequently purely proclamatory. ${ }^{12}$ The world 'credible' or 'credibility' is mentioned 12 times, the accession process as such has to be 'reinvigorated,' the support for the European perspective of the Western Balkans is 'unequivocal,'13

$10 \operatorname{COM}(2020)$ 57, [https://ec.europa.eu/neighbourhood-enlargement/sites/near/files/enlargement-methodology_en.pdf], accessed 20. June 2020

11 This is particularly applicable to the organisation of negotiating chapters in thematic clusters; see sub-section 2.1.2. of this paper

12 For an extensive and highly valuable overview of the various aspects of the use of language in EU law, see Šarčević, S. (ed), Language and Culture in EU Law - Multidisciplinary Perspectives, Surrey, 2015

13 At this stage, it would be appropriate to mention that the support of the member states in the accession process of candidate and potential candidate countries in neither 'unequivocal' nor unanimous. Public opinion in numerous European countries is more and more hostile to the further enlargement, and the 
while an 'accession perspective' is 'the key incentive and driver' of transformation in the region.

Secundo, the closer analysis of the Communication(2020) 57 also reveals the excessive use of prescriptive formulations. The Western Balkans leaders 'must deliver more credibly', while 'both sides should show more leadership'. The noun 'commitment' is mentioned seven times, and Inter-Governmental Conferences (IGCs) 'should provide for stronger political steering.'

Tertio, the level of precision of numerous formulations used in the document is globally low. This is particularly evident in the sub-chapter b), entitled 'A stronger political steer'. While imprecise wording is most often the consequence of the two features mentioned above, sometimes the whole phrases consist of entire blocks of mainly empty and often meaningless phraseology. ${ }^{14}$ For example, both sides 'should (...) live up to their respective commitments in public, while coming in more directly on matters of concern,' while 'further dynamism' should be injected in the process and 'cross-fertilisation' of efforts fostered. ${ }^{15}$

When it comes to the general principles upon which the Communication(2020) 57 is based, the chapter Reinvigorating the accession process comprises four subchapters (a to d), each of them being dedicated to set out 'Commission's concrete proposals for strengthening the whole accession process' ${ }^{16}$ and 'to enhance credibility and trust on both sides and yield better results on the ground. ${ }^{17}$ We will now focus on each of the proposed principles, in the order of their importance, ${ }^{18}$

actual crisis caused by COVID-19 outbreak would only accentuate this tendency; this attitude of the electorate will, sooner or later, result in the new ruling political elites, whose intention to continue and further develop the enlargement would be significantly compromised

14 Some authors have rightly noticed that 'the relatively closed environment of the EU and the patterns of communicative adjustment to the lingua franca often cause native speakers to lose their touch with their mother tongue to the point that government jargon sounds absolutely natural', Felici A., 'Translating EU Legislation from a Lingua Franca: Advantages and Disadvantages', in: Šarčević, S. (ed), Language and Culture in EU Law - Multidisciplinary Perspectives, Surrey, 2015, 123-140

15 The only practical and concrete consequence of the mentioned 'cross-fertilisation' of efforts is the organisation of negotiating chapters in thematic clusters; for more details, see sub-sections 2.1.2. and 2.2.2.

16 Communication (2020) 57, 1

17 Ibid.

18 The structure of the Chapter II (Reinvigorating the accession process) of the Communication (2020) 57 follows the internal logic that, for example, puts the issue of credibility (Subchapter a) before the questions of a stronger political steer (Subchapter b), dynamism of the process (Subchapter c) and predictability, positive and negative conditionality (Subchapter $\mathrm{d}$ ). Notwithstanding the fact that this structure and positioning of the innovative elements of enlargement methodology can be seen as quite consistent and meaningful, this author considers that the issues of political leadership of the process and its temporal dimension have to be put in forward in analysis 
while the scope of possible changes they would entail in the existing enlargement strategy will be examined, following the same structure, in Section 2.2. of this paper.

\subsubsection{Focus on the political nature of the process and stronger steering.}

It is not unusual to hear from various political decision-makers at the national and European level - both in member states and in candidate and potential candidate countries - that the EU should not be seen as a 'money box' or 'piggy bank,'19 whose main purpose is to poor financial resources from various pre-accession funds and through numerous other mechanisms of economic support. Even if it may sound self-evident and merely proclamatory, this element upon which the new enlargement strategy should be based is very important and could have significant, long lasting and down-to-earth consequences. Notwithstanding the fact that the EU has an undisputedly significant economic facet, it is, fundamentally, a value-based community, and this fact should also weigh more in the accession of new member states. Following the wording of the Communication(2020) 57, accession to the EU 'is not moving on autopilot but must reflect an active societal choice ${ }^{20}$ both by political decision-makers and by citizens of candidate countries. When it comes to the stronger steering of the enlargement process, the further analysis shows that the Commission insists on three important elements: 1) intensified 'high level political and policy dialogue' (including regular EU-Western Balkans summits and intensified ministerial contacts); 2) stronger involvement of

19 Of course, the vision of the EU as a 'piggy bank' is not only the exclusive characteristics of the population and politicians in the countries in process of accession. See, for example, the article 'L'Europe n'est pas quiune tirelire' published in 'Courrier Picard' shortly before the European elections and focused on the perception of the purpose of the EU by French citizens, as well as local and regional decision-makers, [https://premium.courrier-picard.fr/id12781/article/2019-05-24/leurope-nest-pas-quune-tirelire], accessed 09. April 2020

20 Communication(2020) 57, 4. Good example of a candidate country in which the accession to the EU is quite far from being 'an active societal choice' is Serbia. In spite of the results of the regular surveys of public opinion published by the country's Ministry of European Integration - which, in general, show that more than $50 \%$ of respondents support membership in the EU - the overwhelming majority of national media, as well as the declarations of the numerous political decision-makers actively promote Euro-sceptic, often anti-European agenda; it was particularly evident during the crisis caused by COVID-19 outbreak, during which relatively modest Chinese support and aid was labelled as 'brotherly aid showing steel-solid friendship', while the substantial aid of the EU was either totally ignored or designated as 'minimal and belated'; for December 2019 results of opinion poll published by the Serbian Ministry of European Integration, see [https://www.mei.gov.rs/upload/documents/ nacionalna_dokumenta/istrazivanja_javnog_mnjenja/opinion_pool_dec_19.pdf]; for an overview regarding EU's and Chinese assistance to Serbia during the crisis caused by COVID-19 outbreak, see [https://europeanwesternbalkans.com/2020/03/30/steel-friendship-between-serbia-and-china-criticised-by-european-commentators/], accessed 11. April 2020 
all bodies under the Stabilisation and Association Agreement (SAA) and 3) more focus on monitoring on the ground (participation of experts, direct contributions to the annual reports and sectoral expertise).

\subsubsection{Dynamisation of the enlargement process, mainly through the organisation of negotiating chapters in thematic clusters.}

As it was often remarked by numerous researchers, ${ }^{21}$ the political conditionality of the accession negotiations and, consequently, the entire enlargement procedure, is becoming lengthier over the years. ${ }^{22}$ However, this element could be applicable only to AL and NM, countries that have recently become candidates for EU membership, while, for the negotiations with MN and SR and Montenegro, 'work on chapters can also be organised around clusters, while respecting the existing negotiating frameworks'. ${ }^{23}$ Given that this new element of enlargement methodology is less focused on general principles than on their practical implementation, it will be more closely examined in sub-section 2.2.2. of this paper.

\subsubsection{Enhanced credibility of the process.}

This principle basically represents the reiteration and accentuation of a rule that should be the crucial element of every bilateral and multilateral international relation - mutual trust, confidence and clear commitments; this is especially applicable when one party (an accession country) strives to fulfil numerous conditions related to the membership in an organisation gathering a number of states sharing common legal heritage, values and complex institutional structure (the $\mathrm{EU})$. However, the wording and the tone of the entire sub-chapter a) of the Communication(2020) 57 indirectly, but very clearly, implies that the legal framework currently applicable to the accession process is far from being satisfactory. Among others, the formulation 'regain credibility' confirms this assessment. ${ }^{24}$ One of the big advantages of this new - or, more precisely, the enhancement and clarification

21 See Masuy-Stroobant, G., (ed), L’élargissement de l,Union européenne: Enjeux et implications, Presses Universitaires de Louvain, Louvain, 2012; Góra, M.; Styczynska, N.; Zubek, M. (eds), Contestation of EU Enlargement and European Neighbourhood Policy - Actors, Areanas and Arguments, Djøf Publishing, Copenhagen, 2019; Staab, A., The End of Europe, independently published, 2020

22 For a global overview of previous waves of enlargement and some major reasons of more and more demanding criteria for new member states, see also Nello, S.S.; Smith, K. E., The European Union and Central and Eastern Europe: The Implications of Enlargement in Stages, Taylor \& Francis Group (Routledge Revivals), London, 2020

23 Communication(2020) 57, 4

24 For the specific case of Turkey and some important generally applicable conclusions, see Zucconi, op. cit., note 6 
of the existing - guiding principle of the new enlargement methodology is that it demands more credibility from both sides involved in the process. On the one hand, 'the Western Balkans leaders must deliver more credibly on their commitment to implement the fundamental reforms required, whether on rule of law, fighting corruption, the economy or ensuring the proper functioning of democratic institutions and public administration, and foreign policy alignment'. ${ }^{25} \mathrm{On}$ the other hand, the counterpart of this requirement addressed to the acceding countries is the obligation of the EU to deliver on its 'unwavering commitment to a merit-based process, ${ }^{26}$ meaning that 'when partner countries meet the objective criteria and the established objective conditions, the Member States shall agree to move forward to the next stage. ${ }^{27}$ Moreover, this is the point where the principle of the enhanced credibility closely imbricates with the one related to the dynamisation of the enlargement process, analysed in the previous sub-section. It is very important to underline that - as the example of unnecessary long and quite often not evidence-based prolongation of the process of the acquirement of the status of candidate country by NM very clearly demonstrates - what really undermines the credibility of the entire EU's enlargement policy is the opposition of certain member states to allow to a (potential) candidate country to move forward in its accession. This is why the mention of the 'objective criteria' and 'established objective conditions,' if not followed by their common interpretation by all member states, would remain empty words devoid of any concrete implications.

\subsubsection{Process characterised by predictability, with positive and negative conditionality as a core element.}

Once again, a 'new' principle of the proposed reform of the enlargement methodology substantially overlaps with one, or even two,${ }^{28}$ guiding rules already introduced by the Communication(2020) 57. It is not necessary to invest particularly high analytical effort in order to conclude that - both in international relations and accession negotiation, but also in numerous other meta-legal and meta-political circumstances - credibility largely relies on predictability. In other words, 'greater clarity on what the Union expects of enlargement countries at different stages of the process ${ }^{29}$ is just a less legal-sounding way to say that the 'objective criteria' and 'established

\footnotetext{
25 Communication(2020) 57, 2

26 Ibid.

27 Communication(2020) 57, 2

28 The reference to 'a stronger political steer,' and the mention that 'the political actors in the countries [...] have a clearer indication of what must be done to move ahead' indicates that the sub-chapter d) of the Communication(2020) 57 also significantly overlaps with subchapter b)

29 Communication(2020) 57, 5
} 
objective conditions' should be known well in advance. At this point, it becomes much clearer why, in the introduction to this chapter, we pointed out that the Communication(2020) 57 is characterised by emphatic and proclamatory style and has globally low level of precision. However, one of the rare indisputably unequivocal and not auto-referential provisions of subchapter $\mathrm{d}$ ) is the one indicating that 'the Commission will better define the conditions set for candidates to progress, in particular through its annual reports, ${ }^{, 30}$ adding that 'these conditions must be objective, precise, detailed, strict and verifiable'. ${ }^{31}$ Consequently, it is evident that a welldefined, uniformly interpreted and strictly applied conditionality is the core element for a successful reform of the EU's enlargement methodology. This is the reason why the another positive element of the proposed new principle is the introduction of negative conditionality, allowing 'more decisive measures proportionally sanctioning any serious or prolonged stagnation or even backsliding in reform implementation and meeting the requirements of the accession process ${ }^{32}$ If every candidate country rightfully expects more clarity from the EU and the strict application of the principle that sufficient progress should lead to the next stage of the accession process, it is also appropriate to introduce the possibility for candidate countries to retrograde in case of serious and proven lack of necessary reforms and harmonisation of national legislation with the Union's acquis. As it was the case for positive conditionality, the criteria for negative conditionality should be defined on clear, objective and verifiable way, while the member states should show a real political will to apply it. Therefore, the new Commission's proposition, in spite of its numerous weaknesses, could represent - once clarified and accompanied with clearer criteria - a solid starting point for a substantially new era in the enlargement of the EU.

\subsection{Major changes the new enlargement strategy would entail}

All general proclamatory principles of the new EU enlargement strategy analysed in the previous section have an intrinsic capacity to bring significant changes in the relations between the EU and the candidate countries, and, consequently, to influence their political and economic future. However, as the previous considerations have demonstrated, the way those principles are formulated, as well as their level of precision and elaboration, leave a significant number of doubts regarding their concrete application and the changes this would entail. ${ }^{33}$ Moreover, CO-

\footnotetext{
$30 \quad$ Ibid.

31 Communication(2020) 57, 5

32 Ibid.

33 As it was already mentioned in the introduction of Chapter 2, enlargement methodology proposed by the Commission will be fully applicable only to AL and NM, while the negotiating frameworks for $\mathrm{MN}$ and SR will not be amended, unless those two countries accept certain accommodations
} 
VID-19 outbreak and global public health crisis it provoked will also leave - for now quite unforeseeable - consequences on all EU policies and on its relations with numerous third parties, including the candidate countries. In this section, all general principles examined in subsections 2.1.1. to 2.1.4. will be analysed from the angle of their major potential consequences. The equal attention will be paid to both potentially negative and potentially positive changes.

\subsubsection{An increasingly politicised negotiation process.}

Until now - and especially at the occasion of the last two waves of enlargement the entire procedure of the accession to the EU was a very technical matter, ${ }^{34}$ left to the highly sub-specialised and initiated experts and, consequently, very distant from the citizens. This is why the Communication(2020) 57 rightly points out that, from the standpoint of candidate countries, the accession is not moving on autopilot but must reflect an active societal choice, ${ }^{35}$ while, on the side of the member states, it should be seen as a 'significant political and not simply technical undertaking. ${ }^{36}$ This observation would have been a good starting point for a substantial reform of enlargement methodology if the Commission had accompanied it with more substantial propositions on how to better involve the citizens (of both member states and candidate countries), in order to present them why the EU should be an active societal choice and a matter of interest for both parties. Especially after COVID-19 outbreak, it would be increasingly difficult to explain to the citizens why the continuation of the enlargement process and integration of the new member states would be a better political choice than the refurbished national sovereignty, more border control and less supra-national solidarity and cooperation. Instead, the Commission proposes more planning, stronger leadership and solider institutional structure. All these elements are undoubtedly important, but it is inappropriate to insist on societal choice and not exclusively technical nature of the enlargement, while proposing reinvigorated politicisation and more top-down approach to the enlargement.

\subsubsection{Clustering of negotiation chapters.}

This is indisputably the most concrete, applicable and potentially beneficial element of the Communication(2020) 57. Even if the principle of a separate opening (and closing) of each negotiation chapter has some important advantages - out

\footnotetext{
34 On technicality and hyper-normativity of the EU's legal system, see Nugent, N., The Government and Politics of the European Union, $8^{\text {th }}$ edition, Palgrave, London, 2017, 97

35 Communication(2020) 57, 3

36 Ibid.
} 
of which some of the most significant are the focus on national legislation and involvement of experts, monitoring of progress and media presence of the EUrelated matters in the candidate countries - their clustering according to the thematic criteria has a great potential to make the entire enlargement process more effective. The screening process would be carried out per cluster, while the 'priorities for accelerated integration and key reforms will be agreed between the EU and the candidate country. ${ }^{37}$ Once these priorities successfully satisfied, the cluster would be 'opened without further conditions and closing benchmarks are set for each chapter'. ${ }^{38}$ Commission's proposition also includes the alignment of clusters with the Stabilisation and Association Agreement sub-committees, limited timeframe between the opening of a cluster and the closing of its individual chapters, and accelerated sectoral alignment and integration. If applied efficiently, responsibly and in good faith, the clustering of negotiation chapters has a great potential to bring more dynamism and transparency to the entire enlargement methodology. Moreover, it could also contribute to reduce some of the negative aspects of topdown approach to politicisation analysed in the previous sub-section, by making the process (at least in some aspects) less technical and by giving to the citizens a clearer picture of what exactly is at stake during the negotiations (broader themes of, for example, good governance, internal market or economic competitiveness).

\subsubsection{Focus on a merit-based process and fundamental reforms.}

As it is the case of numerous other key elements of the new enlargement methodology introduced by the Communication(2020) 57, enhanced credibility of the entire accession process should be based on the commitments of both parties - the EU and the candidate countries. In comparison with the existing negotiation framework, the major changes that would help 'the accession process to regain credibility [...] and deliver to its full potential' are the focus on a meritbased progress of candidate countries, on the one side, and clearer commitment to implement the fundamental reforms, on the other. Once again, the Commission, starting from very pertinent observations on the weaknesses of the existing negotiation framework, fails to give clearer indications on what concretely the new obligations of both parties should consist of. More concretely, how and to which extent the enunciation that, 'when partner countries meet the objective criteria and the established objective conditions, the Member States shall agree to move forward to the next stage of the process ${ }^{39}$ would change the existing practices and already well-known reluctances and (more or less justified) scepticism

\footnotetext{
37 Communication(2020) 57, 4

38 Ibid.

39 Communication(2020) 57, 2
} 
of certain member states? ${ }^{40}$ On the other hand, while it is beyond any doubt that 'EU Member States and citizens have legitimate concerns and need to be reassured of the unequivocal political will of the countries, proven by structural, tangible reforms, ${ }^{\text {,41 }}$ how exactly the obligation of 'Western Balkans leaders' to 'deliver more credibly on their commitment to implement the fundamental reforms required'42 shall be assessed? If we stay in the scope of the reforms proposed by the Communication(2020) 57, and within the framework of the measures it introduces, the most plausible answer would be the reference to the clustering of negotiation chapters and negative conditionality, practically the only two concrete and applicable elements of the new enlargement methodology.

\subsubsection{More clarity through positive and negative conditionality.}

As it was already mentioned in subsections 2.1.4, 2.2.1. and 2.2.3. of this paper, better application of the principle of conditionality - as well as the introduction of negative conditionality in the case of stagnation or backsliding of reforms - is one of the rare aspects where the Communication(2020) 57 proposes substantially innovative and applicable elements of the enlargement strategy. Moreover, the document gives some valuable additional precisions regarding the negative conditionality. On the one hand, the decisions 'to halt or even reverse the process should be informed by the annual assessment by the Commission in its enlargement package on the overall balance in accession negotiations and the extent to which fundamental reforms, in particular on the rule of law are being implemented, ${ }^{2} 3$ while, 'in serious cases, the Commission can make proposals at any time on its own or at the duly motivated request of a Member State in order to ensure a quick response to the situation through, whenever relevant, simplified procedures, including reverse qualified majority voting. ${ }^{44}$ However, both positive and negative conditionality could only bring more clarity and predictability to the accession process if the two additional criteria are cumulatively fulfilled. On the one hand, they should be accompanied by a set of well-defined, uniformly interpreted and strictly applied ${ }^{45}$ criteria; on the other, those criteria should be neither the subject

40 In this regard, the most glaring example was the reticence of France (and some other member states) to grant candidate status to Albania and North Macedonia; for a detailed and well-documented study of this issue, see Eisl, A., Les arguments contestables de la France contre l'élargissement de l'UE, Institut Jacques Delors - Europe dans le monde, [https://institutdelors.eu/publications/frances-questionnable-arguments-against-eu-enlargement/], accessed 13. April 2020

41 Communication(2020) 57, 2

42 Ibid.

43 Communication(2020) 57,5

44 Communication(2020) 57, 6

45 See subchapter 2.1.4. 
of contradictory and 'creative' interpretation by different member states, nor the way to satisfy their purely internal political (most often, election-related) needs, mainly deriving from the pressure from both extreme right and extreme left wing of their national party spectrum.

\section{BETWEEN POLITICAL ENCOURAGEMENT AND ENLARGEMENT FATIGUE - PER COUNTRY REVIEW}

As the previous chapter of this paper strived to demonstrate, the new EU's enlargement strategy could only be a credible alternative to the existing one if it effectively remedies its deficiencies and improves its positive aspects. The main principles introduced by the Communication(2020) 57 are mainly too general, vague and characterised by a low level of precision, ${ }^{46}$ while the major changes it could entail - apart from a few concrete and applicable elements - are still globally unknown. ${ }^{47}$ Given that the new strategy would be fully applicable only to AL and $\mathrm{NM}$, countries that have recently become candidates for EU membership - while, for the accession of MN and SR it could only be effective when it comes to the clustering of negotiation chapters ${ }^{48}$ - the countries of the Western Balkans could find themselves in quite a different positions regarding the rules applicable to the process of their accession to the EU. Without the pretention to bring in-depth analysis of the specificities of each candidate country's national legislation and its position vis-à-vis the accession process, this chapter would strive to give some major indications about the actual state and the possible future developments in this respect. In spite of numerous important differences, the four analysed candidate countries will be grouped (AL-NM and MN-SR) according to the extent to which the new enlargement criteria would be applicable to them.

\subsection{Albania and North Macedonia}

After several unsuccessful attempts to give a decisive incentive to the accession of AL and NM, the EU's General Affairs (GA) Council, on March 25, 2020, has finally adopted the Conclusions on Enlargement and Stabilisation and Association Process, ${ }^{49}$ which were, on the next day, endorsed by the members of the Eu-

\footnotetext{
46 See introduction to chapter 2 and section 2.1.

47 See section 2.2.

48 And this, as pointed out in the introduction to Chapter 2, only with the express consent of each of the two candidate countries

49 Council Conclusions 7002/20, [https://data.consilium.europa.eu/doc/document/ST-7002-2020-INIT/en/pdf], accessed 28. March 2020
} 
ropean Council. ${ }^{50}$ However, the Council also added that it 'looks forward to the Commission's proposals integrating the enhanced approach in future negotiating frameworks and building on applicable established practice under the renewed consensus on enlargement. ${ }^{\prime 51}$ As it has recurrently been underlined in sections 2.1 and 2.2. of this paper, mainly general, often imprecise and proclamatory principles upon which the Communication(2020) 57 is based need to be followed by substantive clarifications, not only in order to be efficiently integrated in the future negotiating frameworks, but also to be more understandable both to the member states and candidate countries. This assessment seems to be implicitly integrated in GA's Council's Conclusions, given that, in this stage of its development, the new enlargement methodology - as the formulation 'applicable established practice' circuitously indicates - represents more a mere political (self)encouragement, than a credible, detailed and applicable new agenda for an improved accession process. This is especially important if one take into consideration the fact that the newly proposed enlargement methodology - unlike it is the case for $\mathrm{MN}$ and $\mathrm{SR}^{52}$ - would be fully applicable to AL and NM. Moreover, the internal complexities of political situation in both countries, as well as the difficulties of the law harmonisation process they encounter, ${ }^{53}$ have a potential to further impede the enthusiasm for EU membership related reforms. On the other hand, the lengthy and laborious process of consensus-building among the member states regarding the opening of accession negotiation with $\mathrm{AL}$ and $\mathrm{NM}$ - to which the COVID-19 outbreak cannot influence but negatively - clearly indicates that the political encouragement desired by the Commission would, most probably, face the wall of internal economic and political difficulties, with a high risk of facing a dead end. As for the country-specific considerations, Council has underlined that, 'prior to the first intergovernmental conference, ${ }^{54} \mathrm{AL}$ should resolve numerous important issues, some of which are: 1) adoption of the electoral reform 'ensuring transparent financing of political parties and electoral campaigns ${ }^{55}$; 2) continued implementation of the judicial reform, 'including ensuring the functioning of the Constitutional Court and the High Court, taking into account relevant international expertise including applicable opinions of the Venice Commission' ${ }^{\text {'56; 3) }}$

\footnotetext{
50 Joint statement of the Members of the European Council, [https://www.consilium.europa.eu/media/43076/26-vc-euco-statement-en.pdf], accessed 28. March 2020

Council Conclusions 7002/20, 3

See the introduction of Chapter 2 and section 3.2. of this paper

See, for example, Hoxhaj, A., The EU Anti-Corruption Report: A Reflexive Governance Approach, Taylor \& Francis, 2019

54 Council Conclusions 7002/20, 5

55 Ibid.

56 Council Conclusions 7002/20, 5
} 
finalisation of 'the establishment of the anti-corruption and organised crime specialised structures ${ }^{57}$; 4) further strengthening of the fight against corruption and organised crime and 5) tackling the phenomenon of unfounded asylum applications. As for NM, the GA Council Conclusions do not mention any specific issue to be resolved before the first intergovernmental conference, but simply 'invites the Commission to continue to monitor the progress and continued compliance in all areas of the conditions identified by the Council in June 2018 related to the opening of negotiations, ${ }^{58}$ as well as 'to carry out and complete the process of analytical examination of the EU acquis. ${ }^{59}$ Consequently, once the issues of the further clarification of the new enlargement strategy and of the laborious consensus-building resolved, it seems that NM is closer to a potentially successful first intergovernmental conference.

\subsection{Montenegro and Serbia}

The elements of the new enlargement methodology brought about by the Communication(2020) 57 can be accommodated within the existing negotiating frameworks with MN and SR only with their agreement. As it was already underlined in sections 2.1 and 2.2 of this paper, given that the clustering of negotiation chapters is one of the rare undoubtedly clear and applicable elements of the proposed new enlargement methodology, it is probable that these two candidate countries - in the limits defined by the existing negotiating frameworks - would accept the organisation of chapters in thematic clusters. However, the membership negotiations with both $\mathrm{MN}$ and, especially, SR, have shown a poor progress in 2019, with either no further chapters provisionally closed (MN) or with only one chapter opened (SR). Both by the number of opened negotiation chapters and by the overall political and media context related to EU integration, MN is more advanced than SR. On the other hand, the absence of a clear political will and functional consensus about the enlargement among the member states is prejudicial for a larger national consensus on the EU accession in both countries, creating the atmosphere where the enlargement fatigue, on the one side, feeds the 'accession fatigue' on the other. In such a context, the Communication(2020) 57 has brought much more of empty political phraseology than of concrete and applicable solutions to reinvigorate the process.

\footnotetext{
$57 \quad$ Ibid.

58 Council Conclusions 7002/20, 4

59 Ibid.
} 


\section{CONCLUSION}

Recently, there has been practically no disagreement among researchers regarding the assessment that the enlargement process of the EU is at a standstill. While Albania and North Macedonia, in addition to their internal difficulties, have been faced to lengthy and laborious process of consensus-building among the member states regarding the opening of accession negotiation, Montenegro and Serbia have shown a poor progress in 2019, with either no further chapters provisionally closed (MN) or with only one chapter opened (SR). In such a context, the Commission Communication(2020) 57 on 'Enhancing the accession process - A credible EU perspective for the Western Balkans,' had hardly brought any significant and applicable solutions. Characterised by emphatic and proclamatory style, excessive use of prescriptive formulations and globally low level of precision, the newly proposed enlargement methodology needs to be followed by substantive clarifications, not only in order to be efficiently integrated in the future negotiating frameworks, but also to be more understandable both to the member states and candidate countries. The Commission, starting from very pertinent observations on the weaknesses of the existing negotiation framework, fails to give clearer indications on what concretely the new obligations of both parties should consist of. Moreover, the global public health crisis caused by the SARS-CoV-2 virus (and COVID-19 outbreak it provoked) puts the entire issue of enlargement further down on the agenda of the Union's policy priorities. Therefore, the absence of a clear political will and functional consensus about the enlargement among the member states, on the one hand, and numerous internal political, institutional and value-related difficulties and uncertainties in the candidate countries, on the other, create the atmosphere where the enlargement fatigue, on the one side, feeds the 'accession fatigue' on the other. Even if the wish of an encouragement is undoubtedly present, the future of the EU enlargement still remains decidedly unclear.

\section{REFERENCES}

\section{BOOKS AND ARTICLES}

1. Berger, H.; Moutos, T. (eds), Managing European Union Enlargement, The MIT Press, Cambridge 2004

2. Börzel, T., States and Regions in the European Union - Institutional Adaptation in Germany and Spain, Cambridge University Press, Cambridge, 2002

3. Felici, A., 'Translating EU Legislation from a Lingua Franca: Advantages and Disadvantages', in: Šarčević, S. (ed), Language and Culture in EU Law - Multidisciplinary Perspectives, Surrey, 2015, pp. 123-140

4. Gateva, E., European Union Enlargement Conditionality, Palgrave Macmillan, 2016 
5. Góra, M.; Styczynska, N.; Zubek, M. (eds), Contestation of EU Enlargement and European Neighbourhood Policy - Actors, Areanas and Arguments, Djøf Publishing, Copenhagen, 2019

6. Hoxhaj, A., The EU Anti-Corruption Report: A Reflexive Governance Approach, Taylor \& Francis, 2019

7. Ikonomou, H.; Andry, A.; Byberg, R. (eds), European Enlargement accross Rounds and Beyond Borders, Routledge, London, 2017

8. Kaiser, W.; Elvert, J. (eds), European Union Enlargement: A Comparative History, Routledge, 2004

9. Masuy-Stroobant G. (ed.), L'élargissement de l’Union européenne: Enjeux et implications, Presses Universitaires de Louvain, Louvain, 2012

10. Nello, S.S.; Smith, E.K., The European Union and Central and Eastern Europe: The Implications of Enlargement in Stages, Taylor \& Francis Group (Routledge Revivals), London, 2020

11. Nugent, N., The Government and Politics of the European Union, $8^{\text {th }}$ edition, Palgrave, London, 2017

12. Staab, A., The End of Europe, independently published, 2020

13. Šarčević S. (ed), Language and Culture in EU Law - Multidisciplinary Perspectives, Surrey, 2015

14. Zimmermann, H.; Dür, A. (eds.), Key Controversies in European Integration (2 ${ }^{\text {nd }}$ edition), Palgrave, London 2016

15. Zucconi, M., EU Influence Beyond Conditionality: Turkey Plus/Minus the EU, Palgrave Macmillan, Cham, 2020

\section{EU LAW}

1. General Affairs Council - Council Conclusion 7002/20 of 25 March 2020, accessible at [https://data.consilium.europa.eu/doc/document/ST-7002-2020-INIT/en/pdf]

2. Communication (2020) 57) of February 5, 2020 from the Commission to the European Parliament, the Council, the European Economic and Social Committee and the Committee of the Regions on 'Enhancing the accession process - A credible EU perspective for the Western Balkans', accessible at [https://ec.europa.eu/neighbourhood-enlargement/sites/ near/files/enlargement-methodology_en.pdf]

3. Joint statement of the Members of the European Council, accessible at [https://www.consilium.europa.eu/media/43076/26-vc-euco-statement-en.pdf]

\section{WEBSITE REFERENCES}

1. Eisl, A., 'Les arguments contestables de la France contre l'élargissement de l'UE, Institut Jacques Delors - Europe dans le monde, [https://institutdelors.eu/publications/francesquestionnable-arguments-against-eu-enlargement/g, accessed 13. April 2020

2. 'L'Europe n'est pas qu'une tirelire', 'Courrier Picard', [https://premium.courrier-picard.fr/ id12781/article/2019-05-24/leurope-nest-pas-quune-tirelire], accessed 09. April 2020 
3. Website of the Croatian presidency of the EU, Croatian Presidency postpones informal meetings in Croatia until 15 May [https://eu2020.hr/Home/OneNews?id=236], accessed 13. April 2020

4. Website of the Croatian presidency of the EU, On the initiative of Prime Minister Andrej Plenkovic, Zagreb Summit will be held May 6th via video conference, [https://eu2020.hr/ Home/OneNews?id=257], accessed 20. June 2020 